\title{
Paulina Szydeowsika
}

JOANNA DURLIK

JOANNA GRZYMALA-MOSZCZYŃSKA

Halina Grzymala-MoszCZYŃSKa

\section{(Nie)równe traktowanie dzieci powracających w polskiej szkole}

Streszczenie: Celem badań, które zostały przeprowadzone w ramach projektu (Nie)tatwe powroty do domu. Badanie funkcjonowania dzieci i mtodzieży powracajacych z emigracji, było zdiagnozowanie sytuacji dzieci i młodzieży powracających do Polski i opisanie jej z różnych perspektyw: dziecka, rodzica, nauczyciela/ki, a także osób pracujących w poradniach psychologiczno-pedagogicznych. W badaniach wzięło udział 34 dzieci, 27 rodziców oraz 26 nauczycieli. Z respondentami i respondentkami przeprowadzono częściowo pogłębione wywiady, a z pracownikami Poradni Psychologiczno-Pedagogicznych wywiady focusowe oraz badanie ankietowe.

Wyniki badań wskazują na występowanie dyskryminacji w stosunku do dzieci powracających w polskich szkołach. Przybiera ona różne formy: od nieuwzględniania przez szkołę ich specjalnych potrzeb edukacyjnych, przez etykietowanie, po przemoc słowną albo fizyczną ze strony rówieśników. Badania pokazują również, że często kadra szkolna nie tylko nie reaguje adekwatnie na przemoc stosowaną względem tej grupy dzieci, ale sama dopuszcza sie takiej przemocy w sposób nieświadomy. Sytuacja ta może wynikać zarówno z braku przygotowania nauczycieli do pracy $\mathrm{z}$ dzieckiem $\mathrm{z}$ doświadczeniem migracyjnym $\mathrm{w}$ ramach studiów, a także z braku dostępu do szkoleń na temat edukacji antydyskryminacyjnej.

Słowa kluczowe: dyskryminacja, migracja, dzieci, środowisko szkolne, uprzedzenia

\section{Wstęp}

Nasz artykuł przedstawia analizę problemu dyskryminacji dzieci z polskich rodzin powracających z emigracji poprzez usytuowanie tego zagadnienia w kontekście zarówno teorii opisujących zjawisko dyskryminacji, jak i praktyki funkcjonującej w polskim systemie edukacji. 


\section{Dyskryminacja i jej źródła/przyczyny}

Istnieje wiele definicji dyskryminacji. Idąc za Wojciszke (2013), pojęcie dyskryminacji można zdefiniować jako wrogie lub niesprawiedliwe zachowanie wobec osób należących do stereotypizowanej grupy - na podstawie uprzedzeń względem samej grupy, a nie indywidualnych własności danego człowieka. Stereotypizowana grupa to taka, którą ocenia się pod kątem uproszczonego schematu wyodrębnionego z uwagi na łatwo zauważalną cechę, która określa ich społeczną tożsamość, jak np. płeć, narodowość, rasa, wiek czy zawód. Aronson i in. (1997, za: Jonczy-Adamska, 2015) piszą o dyskryminacji jako komponencie uprzedzenia, które definiują jako wrogą bądź negatywną postawę, która dotyczy grupy ludzi. Oparta jest ona wyłącznie na przynależności osoby do tej grupy. Uprzedzenie składa się z trzech komponentów: stereotypu (komponentu poznawczego, myśli i przekonań na temat danej grupy), uprzedzenia (określającego - poza całą postawą - również jej komponent emocjonalny) oraz dyskryminacji (komponentu behawioralnego) (Jonczy-Adamska, 2015, s. 199).

Znanych jest wiele teorii dotyczących rozwoju uprzedzeń u dzieci. Jedną z nich jest społeczno-kognitywna teoria rozwoju uprzedzeń (Socio-Cognitive Theory) autorstwa Frances Aboud (2005). Opisuje ona stadialny rozwój uprzedzeń związany z rozwojem poznawczym dziecka. Zgodnie z nią dzieci przechodzą kolejno przez stadium emocjonalne (dzieci lubią to, co jest im znane), percepcyjne (dzieci lubią to, co jest do nich podobne) i poznawcze. Będąc w tym ostatnim stadium dziecko przestaje polegać na kategoryzacji jako głównym mechanizmie tworzenia ocen, a zaczyna kontrolować wiedzę na temat nabytych kategorii dotyczących grup ludzi, czyli ocenia osoby nie tylko z perspektywy grup, do których należą, ale też potrafi dostrzegać i uwzględniać wewnętrzne cechy indywidualnych jednostek.

Drew Nesdale natomiast w swojej teorii rozwoju tożsamości społecznej (Social Identity Development Theory, SIDT) (2007, za: Nesdale, 2013) wskazuje na fakt, iż negatywne uprzedzenia mogą się kształtować dopiero po 6.-7. roku życia, kiedy duże znaczenie dla dziecka zaczyna mieć przynależność do grupy rówieśniczej (Rubin, Bukowski i Parker, 1998, za: Nesdale, 2013). W sposób naturalny młodsze dzieci przejawiają preferencje względem własnej grupy. Rozwój negatywnych uprzedzeń międzygrupowych jest końcowym punktem procesu, który zależy nie tylko od możliwości poznawczych dziecka, ale też od wpływu na dziecko podzielanych przez środowisko norm 
i przekonań względem grupy zewnętrznej. Zaczyna się on od etapu niezróżnicowania (do 2.-3. r.ż.) następnie przechodzi w preferencję etniczną (po 2.-3. r.ż. dzieci preferują członków własnej grupy etnicznej, gdyż jest ona postrzegana jako posiadająca więcej pozytywnych cech) po kształtowanie się uprzedzeń etnicznych (po 6.-7. r.ż. zależy od tego, jak bardzo dzieci identyfikują się z własną grupą i grupą zewnętrzną oraz na ile ta identyfikacja jest normą podzielaną przez członków grupy własnej). Obie teorie wskazują, że rozwój uprzedzeń jest naturalnym procesem poznawczym związanym z rozwojem mechanizmu kategoryzacji, ale też znacznie uzależnionym od wpływu środowiska. Dopiero po osiągnięciu pewnej dojrzałości poznawczej dziecko może kontrolować uprzedzenia względem członków poszczególnych grup zewnętrznych.

Istotna jest również zależność między zjawiskiem dyskryminacji oraz władzy. Ta ostatnia prowadzi do występowania asymetrycznych relacji międzygrupowych i/lub międzyludzkich oraz traktowania osób uprzywilejowanych jako nadrzędnych względem innych. Władza może mieć charakter formalny (w kontekście szkolnym na przykład: uczeń - nauczyciel) lub nieformalny (uczeń z grupy większościowej oraz uczeń z grupy mniejszościowej), ale w obu wypadkach sytuacja władzy pozwala na wykorzystanie wysokiej pozycji w celu traktowania osób stojących niżej w hierarchii nierówno, przy czym osoba o wysokiej pozycji najczęściej kieruje się swoimi stereotypami i uprzedzeniami (Cieślikowska, 2010, za: Chustecka, Dymowska i Stoecker, 2015).

Ostatnią teorią, która wydaje się relewantna dla niniejszego tekstu, jest zintegrowana teoria uprzedzeń, sformułowana przez Stephan i Stephan (2000, za: Wojciszke, 2013). Autorzy stwierdzają, że źródłem negatywnych postaw międzygrupowych są nie tylko konflikty interesów i wartości, lecz także lęk i negatywne stereotypy. Lęk międzygrupowy to strach i niepewność w kontakcie z członkami grupy obcej wynikające z podejrzewania ich o wrogie intencje oraz z nieznajomości wzorców ich myślenia i postępowania, co w konsekwencji prowadzić może do zachowań dyskryminacyjnych względem członków „grupy obcej” (Wojciszke, 2013).

Każda z powyżej opisanych teorii zawiera przesłanki pozwalające sądzić, że szkoła jest środowiskiem, w którym zjawisko dyskryminacji może występować. Dzieci na tym etapie rozwoju nabywają kompetencje do kontrolowania stereotypów, ale też znacznie wzrasta rola środowiska rówieśniczego, od którego zależy, czy istniejące schematy poznawcze związane z konkretnymi grupami będą się usztywniać czy modyfikować. Z drugiej strony, zarówno w środowisku rówieśniczym, jak i nauczycielskim występują asymetryczne 
relacje władzy, co może uruchamiać zachowania dyskryminujące. Przedstawione poniżej badania własne będą próbą odpowiedzi na pytanie o to, jak szkolna sytuacja dzieci z polskich rodzin powracających z emigracji może zostać zinterpretowana przez pryzmat istniejących przesłanek do wystąpienia wobec tych dzieci zachowań dyskryminujących.

\section{Dyskryminacja w szkole}

Pojęcie dyskryminacji w niniejszym artykule definiujemy szeroko. Rozumiemy pod nim zarówno nierówne traktowanie charakteryzujące się np. arbitralną odmową dostępu do dóbr lub możliwości, ale także jako motywowaną uprzedzeniami przemoc fizyczną, werbalną i symboliczną pod postacią mowy nienawiści. Podobnie szerokie rozumienie dyskryminacji odnaleźć można np. we wspomnianym powyżej raporcie TEA (Gawlicz, Rudnicki i Starnowski, 2015).

Badania pokazują, że doświadczanie dyskryminacji ze strony zarówno rówieśników, jak i nauczycieli jest źródłem stresu, który wpływa na dobrostan psychiczny i fizyczny dziecka (Grant i in., 2004, za: Grzymała-Moszczyńska i Stoecker, 2015), a w konsekwencji na proces uczenia się. Uczenie się, zgodnie z teorią potrzeb Abrahama Maslowa, należy do grupy potrzeb wyższego rzędu. Mogą one być spełnione, gdy zaspokojone zostaną potrzeby podstawowe, takie jak potrzeba bezpieczeństwa czy potrzeby fizjologiczne (Maslow, 1948, za: Grzymała-Moszczyńska i Stoecker, 2015). Na potrzebę bezpieczeństwa składają się takie aspekty, jak bycie akceptowanym czy brak poczucia zagrożenia.

Badania przeprowadzone w polskich szkołach przez Towarzystwo Edukacji Antydyskryminacyjnej (Chustecka, Dymowskai Stoecker, 2015) wskazują m.in., że najczęstszą przesłanką niesprawiedliwego traktowania ze strony rówieśników w szkole jest status społeczno-ekonomiczny. Inne to m.in. orientacja seksualna, płeć, niepełnosprawność, doświadczanie choroby, wygląd, wiek czy doświadczenie migracyjne. Ta ostatnia wynika nie tylko z odmiennego (niż polskie) pochodzenia i nieznajomości języka, ale także z innego (niż dominujące w Polsce) wyznania czy, w niektórych przypadkach, koloru skóry. Autorki badania podkreślają też, że aby doświadczyć nierównego traktowania, niekoniecznie trzeba pochodzić z innego kraju, wystarczy bowiem przeprowadzić się z terytorium symbolicznie traktowanego jako „swoje”. Analiza takiego „terytorialnego” konfliktu między uczniami polskimi i czeczeńskimi została przeprowadzona w jednej ze śląskich szkół. Sporne terytorium oka- 
zało się wówczas najwyraźniej artykułowaną przyczyną sporu i dyskryminacji uczniów czeczeńskich w szkole (Grzymała-Moszczyńska i Trojanek 2011). Zaobserwowane zachowania obejmują katalog form gorszego traktowania od stygmatyzowania, przez wyzwiska, wyśmiewanie, paternalizm, podwójne standardy, faworyzowanie, do deprecjonujących komentarzy pod adresem osób z grup mniejszościowych.

Szkoła powinna dbać o to, aby przeciwdziałać zjawisku dyskryminacji, w celu zapewnienia dzieciom właściwych warunków do uczenia się. Próby można zaobserwować m.in. w aktualnej podstawie programowej, która odwołuje się do „kształtowania postawy obywatelskiej, postawy poszanowania tradycji i kultury własnego narodu, a także postawy poszanowania dla innych kultur i tradycji". Szkoła podejmuje odpowiednie kroki w celu zapobiegania wszelkiej dyskryminacji" ${ }^{1}$, we fragmentach ustawy o systemie oświaty czy zapisach dotyczących przeciwdziałania dyskryminacji, które wprowadza System Ewaluacji Oświaty (Grzymała-Moszczyńska i Stoecker, 2015). Mimo to w szkołach nadal obserwuje się zjawisko dyskryminacji, co zostało szeroko opisane m.in. w raporcie Towarzystwa Edukacji Antydyskryminacyjnej Dyskryminacja - obecność nieusprawiedliwiona (Gawlicz, Rudnicki i Starnowski, 2015). Badania te, prowadzone na szeroką skalę, opisały również sytuację dzieci z doświadczeniem migracyjnym. Nie opisywały jednak bezpośrednio sytuacji grupy dzieci powracających z emigracji polskich rodzin. Poniżej przedstawiamy opis trudności, z jakimi mierzą się dzieci z tych rodzin, w celu przybliżenia źródeł mechanizmu pojawiania się zachowań dyskryminujących w stosunku do tej grupy dzieci.

\section{Kim są dzieci z rodzin powracających do Polski?}

Dzieci z rodzin powracających z emigracji należą do grupy dzieci z doświadczeniem migracyjnym. Często są tak zwanymi „migrantami ukrytymi” lub „niewidocznymi”, ze względu na ich polskie imiona i nazwiska i posługiwanie się językiem polskim w życiu codziennym. Gdy takie dziecko trafia do polskiego systemu edukacji, na początku może się wydawać, że nie powinno mieć żadnych problemów z adaptacją, bo nie przyjeżdża do nowej, lecz do znajomej kultury, i że szybko nadrobi ewentualne szkolne zaległości dzięki

1 Podstawa programowa kształcenia ogólnego dla szkół podstawowych, s. 2. Podobne zapisy zawierają podstawy programowe obowiązujące na kolejnych etapach edukacyjnych (Grzymała-Moszczyńska i Stoecker, 2015). 
polskim korzeniom i znajomości języka. Tymczasem dzieci te często przejawiają bardzo podobne trudności do tych doświadczanych przez dzieci cudzoziemskie trafiające do polskiego systemu edukacji. Wynika to po pierwsze z faktu, że dzieci, które wyjechały z rodzicami jako niemowlęta czy kilkulatki, lub urodziły się za granicą, faktycznie emigrują do Polski, którą znają jedynie z wyjazdów wakacyjnych i opowieści. Tylko o rodzicach można powiedzieć, że wracają (Zuniga i Hamann, 2014).

Poważną trudnością, której doświadcza ta grupa, są bariery językowe, występujące nawet wówczas, gdy dziecko dobrze posługuje się mówioną polszczyzną. W szkole trudności dotyczą głównie ortografii, ale też braku znajomości słów specyficznych dla danej dziedziny nauki, jak np. matematyczne słownictwo („obwód”, „średnica” czy „pole” etc.), tempa czytania czy braku znajomości slangu młodzieżowego. Inną trudnością ściśle związaną z nabywaniem wiedzy są różnice programowe, które dziecko musi nadrabiać. Łatwo sobie wyobrazić, że takim przedmiotem może być historia Polski czy zajęcia, które w innych systemach edukacji połączone są w jeden przedmiot, np. „science” (nauka), na które składają się: chemia, fizyka, matematyka (Grzymała-Moszczyńska i in., 2015).

Kolejnym wyzwaniem wynikającym z dorastania w innym kontekście kulturowym jest brak znajomości zasad i norm panujących w polskiej szkole. Jednym z przykładów takiego zachowania jest zwracanie się do nauczyciela po imieniu lub podawanie mu/jej ręki na pożegnanie, co w polskiej szkole może być traktowane jako niepożądane skracanie dystansu w stosunku do nauczyciela. Takie zachowanie w naszym kontekście kulturowym może być uważane za "niegrzeczne”, może być też powodem do szyderstw ze strony rówieśników. Związane jest to z wymiarem kulturowym określonym jako dystans władzy (Hofstede, 1980, 1983, za: Matsumoto, 2007)². W krajach o wysokim dystansie władzy nauczyciel jest traktowany z szacunkiem, uczniowie wstają, gdy wchodzi do klasy. Jest odpowiedzialny za proces edukacyjny, wszystkie formy komunikowania są inicjowane przez niego, krytykowanie nauczyciela jest niedopuszczalne (Hofstede, 2007). Niski dystans władzy

2 Hofstede (1980, 1983, za: Matsumoto, 2007) przeprowadził analizę wartości kulturowych wśród pracowników firmy IBM z ponad 50 krajów. Wyniki pozwoliły mu na opisanie pięciu wymiarów charakteryzujących kultury - indywidualność-kolektywizm, męskość-kobiecość, unikanie niepewności oraz dystans władzy. Ten ostatni odnosi się do stopnia nierówności władzy między jednostką o mniejszej władzy a osobą mającą większą władzę. Samo pojęcie wymiaru dotyczy ogólnych tendencji, które wpływają na zachowania i odzwierciedlają istotne aspekty zmienności kulturowej (Matsumoto, 2007). 
zakłada relację partnerską, to uczeń jest podmiotem procesu edukacyjnego, ceni się jego zdanie i własną inicjatywę. W krajach niemieckojęzycznych i skandynawskich oraz Stanach Zjednoczonych i Wielkiej Brytanii, z których często powracają polskie rodziny, wskaźnik dystansu władzy na proponowanej przez Hofstede skali jest niski. W Polsce z kolei dystans władzy jest stosunkowo wysoki, co może generować różne nieporozumienia zarówno $\mathrm{w}$ relacji między dzieckiem z rodziny powracającej a nauczycielem, ale również między nim a grupą rówieśniczą.

Ostatnim aspektem związanym ze specyficzną sytuacją dzieci z rodzin powracających jest możliwość doświadczenia stresu adaptacyjnego, zwanego inaczej szokiem kulturowym. Został on zdefiniowany przez Carla Oberga (1960, za: Czarnecka, 2012) jako zaburzenie funkcjonowania psychosomatycznego wywołane przedłużającym się kontaktem z inną i nieznaną kulturą. W związku z czym dana osoba doświadczać może silnego napięcia, reakcji stresowych, uczucia dezorientacji, frustracji oraz bezradności w związku z brakiem znajomości skryptów kulturowych.

Może on wpływać na funkcjonowanie poznawcze i społeczne dziecka. Przejawia się on zarówno pod postacią somatyczną poprzez bóle głowy, brzucha, spadek odporności, jak i behawioralnie poprzez m.in. napady złości, spadek nastroju. Ten problem został szeroko opisany m.in. w raporcie z badań „(Nie) łatwe powroty do domu. Badanie funkcjonowania dzieci i młodzieży powracających z emigracji”', a wskazówki dotyczące wspierania dziecka w procesie doświadczania różnorodnych emocji związanych z sytuacją migracji można znaleźć w publikacji Dzieci leca pierwsza klasa, autorstwa Anny Jurek (2015)4.

Wszystkie wymienione trudności mogą wywoływać u dziecka poczucie wyobcowania, braku przynależności do grupy, do której trafiło, brak zrozumienia norm i zasad panujących w nowym systemie szkolnym. Prowadzić to może zarówno do braku poczucia bezpieczeństwa, jak i szczególnych, wyróżniających się zachowań dziecka, które z kolei mogą prowadzić zarówno do braku akceptacji dziecka ze strony rówieśników, jak i wykluczenia społecznego. Zatem - choć może się to wydawać zaskakujące - dzieci z rodzin powracających mogą doświadczać dyskryminacji ze względu na sytuację migracji, która wiąże się z przynależnością do „grupy obcej”.

3 Projekt powstał we współpracy Fundacji Centrum im. prof. Bronisława Geremka i Uniwersytetu Jagiellońskiego, przy wsparciu finansowym Fundacji PZU.

4 Publikacja dostępna jest pod adresem: http://ffrs.org.pl/wp content/uploads/ FRS_Dzieci_leca_2015_www_FIN.pdf. 
Celem badania w ramach projektu (Nie)tatwe powroty do domu. Badanie funkcjonowania dzieci i młodzieży powracajacych z migracji była eksploracyjna analiza sytuacji dzieci z rodzin powracających. Jeden ze zdiagnozowanych przez nas obszarów dotyczy aspektów związanych z doświadczaną przez tę grupę dzieci dyskryminacją ze względu na ich doświadczenie migracyjne, co postaramy się przybliżyć w niniejszym tekście.

\section{Metoda}

\section{Osoby badane}

W badaniu wzięło udział 34 dzieci i młodzieży (20 dziewczynek i 14 chłopców), w wieku od 5 do 20 lat $(M=10.5 ; S D=3.39)$; 27 rodziców (25 matek, 2 ojców); 25 nauczycielek i jeden nauczyciel. Z całej grupy badanej 30\% (10 dzieci) doświadczyło w szkole dyskryminacji pod postacią przezwisk - przemocy słownej, a dwójka doświadczyła przemocy fizycznej.

\section{Narzędzia}

Ze wszystkimi osobami uczestniczącymi w badaniu przeprowadzono częściowo ustrukturyzowane wywiady: punktem wyjścia do każdej z rozmów była ustalona lista pytań, którą każdorazowo badaczka mogła rozbudowywać w zależności od wątków wprowadzanych przez osobę badaną (StemplewskaŻakowicz, 2009). W celu nawiązania kontaktu badania z dziećmi do 9 lat wspierane były dodatkowymi narzędziami: rysunkiem (na początku spotkania proszono dziecko o narysowanie domu w Polsce i za granicą), wspólną lekturą bajki przedstawiającej historię żółwia-migranta oraz rozmową na temat bajki. Wprowadzenie tych form miało na celu przede wszystkim nawiązanie kontaktu między dzieckiem a badaczem. Same wytwory dzieci nie były analizowane, rysunek i bajka stanowiły ewentualnie punkt wyjścia do rozmowy z dzieckiem na temat jego doświadczeń migracyjnych.

\section{Procedura}

Wywiady zostały przeprowadzone w miejscu zamieszkania osób badanych lub w szkołach. Osoby badane najpierw były informowane o celu badania, jego anonimowości, a także możliwości rezygnacji z udziału, a następnie proszone zostały o podpisanie zgody na udział w badaniu. Zgodę na udział w badaniu dzieci do 16. roku życia podpisywał rodzic. Zgodę na udział młodzieży w wieku od 16 do 20 lat podpisywał zarówno rodzic, jak i sam respondent/ respondentka. Żadna z osób badanych nie przerwała udziału w badaniu. 


\section{Wyniki}

Analizy wywiadów wskazują, że 8 z 34 przebadanych w projekcie uczniów i uczennic doświadczyło przemocy werbalnej, a dwoje dzieci przemocy fizycznej w szkole. Opis wyników badania zostanie podzielony na trzy części opisujące poszczególne obszary, w ramach których dzieci powracające doświadczają dyskryminacji. Pierwszy z nich odnosi się do relacji w grupie rówieśniczej, drugi dotyczy interakcji z nauczycielami, a trzeci dyskryminacji w kontekście systemowym 5 .

\section{Dyskryminacja w grupie rówieśniczej}

\section{Przemoc werbalna}

Przemoc i dyskryminacja słowna, której doświadczyły dzieci z rodzin powracających, polegała głównie na przezywaniu dzieci etykietami związanymi z nazwą kraju, z którego przybyły, jak np. „Niemiec/Niemka”, „Hiszpan” czy „Franszua”. Zarówno dzieci, rodzice, jak i nauczyciele podkreślali w wywiadach, że określenia te były wymawiane z pejoratywnym wydźwiękiem i były używane przez innych uczniów jako szyderstwa. Z przytoczonych cytatów można wnioskować, że po pewnym czasie, przynajmniej w niektórych przypadkach, zachowania te ustępowały.

Ale nie wiem czy to ma bezpośredni zwiazek z tym, że właśnie wyjeżdżała... znaczy potem miała taki też problem, że jakoś bardzo uczniowie byli negatywnie do niej nastawieni, nie do końca wiem dlaczego, też na poczatku ja przezywali - „Niemka, Niemka”, ale to byto tak nacechowane, tak bardzo negatywnie. Ona bardzo to brata do siebie. W tym momencie, no to już sie w ogóle tym przezwiskiem nie przejmuje (nauczyciel 15-letniej dziewczynki).

Nie, ale za to pamiętam, jak pierwszy raz sie pokazałem kolegom. $B^{6}$ : Co zrobiłeś? R: Jak pierwszy raz sie pokazatem kolegom na dole. B: Aha, i jak byto? R: Gtupio. B: Gtupio, czemu? R: Bo się ze mnie naśmiewali. B: O jej, dlaczego? R: Bo bytem z Hiszpanii. B: Aha, a śmiali się, bo byteś $w$ Hiszpanii, ale potem przestali? R: Yhym. (...). B: Przezywali Cię? Jak Cię przezywali? R: Franszua. B:

5 Wszystkie cytaty pochodzą z materiałów zgromadzonych w projekcie (Nie)tatwe powroty do domu. Badanie funkcjonowania dzieci i młodzieży powracajacych z emigracji.

6 W transkrypcjach wywiadów litera B oznacza zawsze Badaczkę, $\mathrm{R}$ - respondenta/respondentkę. 
To ciekawe. I co im wtedy mówiłeś? R: Wtedy to szłem za blok. A jak to byto za blokiem, to szłem na dziedziniec. B: A dziewczynka, która Cię tak przezywała, teraz jest twoją, koleżanki najlepsza, nie? (chłopiec, 13 lat, i jego mama).

Kiedy chodzitam do szkoty, nie podobało mi się zbyt. Dlatego, że wszyscy mnie wyzywali „patrzcie, ta dziwna $z$ Włoch przyszła”. Wszyscy ode mnie uciekali i tylko takie... ta dziewczynka Wiktoria, to ona akurat... my się razem interesowatyśmy malowaniem i zwierzętami (dziewczynka, 8 lat).

Mhm, a przeszkadzaja ci? R: Y, czasem. B: To co, co robia? R: No nie zawsze, ale, rzadko, bo czasem jest tak, że wyzywa mnie ten chtopak nowy. B: Niegrzeczny taki? R: Tak, on mnie czasem wyzywat coś tam, nie pamiętam co dokładnie, ale coś tam, że byłam w Anglii, jestem nieukiem, coś takiego. Ale teraz już przestat (dziewczynka, 8 lat).

A jak wrócitem do Polski, to też byty takie osoby, które się ze mnie śmiały i też chciaty mnie przygnębić, bo mówity, że jest (Niemcem), tak, to byto takie... Znaczy teraz ja to po prostu ignoruje, bo jest to tak, takie nie powiedziatbym codzienność, ale jest to dosyć częste, więc śmieszy mnie to, można tak powiedzieć (chłopiec, 15 lat).

Rodzice relacjonowali, że dzieci dziwiły się, dlaczego rodzaj diety, nazwisko czy wygląd może być powodem wyśmiewania. Nie były bowiem do tego przyzwyczajone w szkołach za granicą, w których dotychczas pobierały edukację. Zarówno rodzice, jak i dzieci relacjonowali brak reakcji na obraźliwe zachowania ze strony nauczycieli. Jest to zbieżne $\mathrm{z}$ wynikami badań prowadzonych m.in. przez Towarzystwo Edukacji Antydyskryminacyjnej (Gawlicz, Rudnicki, Starnawski, 2015), które również wskazują na powszechne występowanie zjawiska dyskryminacji w szkole.

I mówię, to jest takie obrażanie, „Ty się ubierasz w szmateksie, Twoja matka chodzi”... takie teksty u dzieci. To się w głowie nie mieści (...). No i mówię, nawet nauczyciel nie reaguje, nie wiem, dyscypliny żadnej nie ma, po prostu tragedia (mama 9-letniej dziewczynki).

\section{Przemoc fizyczna}

Dwójka dzieci, które wzięły udział w badaniu, doświadczyły przemocy fizycznej. Niepokojące jest, że w jednym przypadku matka relacjonowała brak reakcji ze strony nauczycieli na zaistniałe zachowania. W drugim badany przez 
nas chłopiec zaznaczył, że reakcja się pojawiła - nauczycielka upomniała kopiącego chłopca.

B: A powiedz mi, a pomagasz kolegom czasem i koleżankom $w$ klasie? R: Wangielskim? B: Tak. R: Yhym. B: Tak? A jak to robisz? Pani cię prosi czy sam im pomagasz? R: Jak mnie prosza, to im na przyktad... często mnie taki jeden... no, to nie jest mój kolega, bo jego przywitanie do mnie to byto kopnięcie mnie w brzuch. Jak przysztem do szkoty pierwszy dzień. B: A dlaczego on to zrobit? R: No, bo on jest taki, no wtaśnie, niedobry. B: A powiedziałeś o tym pani? R: Yhym. B: I co ona zrobiła? Powiedziała, że jeszcze raz tak zrobi, a pójdzie do pani dyrektorki, bo on już nie raz tak robił (chłopiec, 9 lat).

One sa, one sq wychowane tak, że się nie oszukuje, tak tam ucza. Nie oszukuje się, nie bije się jeżeli ktoś... Trzy razy już została pobita w szkole przez dzieci inne. Spokojne dziecko, które nie zaczyna, nic się nie dzieje trzy razy nauczycielka... A: Nic nauczycielka nie wie... B: No co... Zwracała mu uwage no i co? Co ja moge więcej? A: Mhm. Ale wiadomo, jakie byty... co się wydarzyto przedtem? B: No tak. No po prostu tak, bo tam się bawity z kimś innym, niż ono chciało. A on chciat $z$ nimi... a one się nie chciaty $z$ nim bawić. No to... Jedno w ogóle nie wiadomo w ogóle o co chodzito. Po prostu podbiegł do niej $z$ tytu i ja... i z wyskoku ja kopnat. Nikt, nikt nie wie ani inne dzieci, ani on nawet nie umie powiedzieć, dlaczego tak zrobit. Nie wiadomo, o co chodziło. Dziecko przyszto posiniaczone ze szkoty, tego to nawet nauczycielka nie widziata. No ale dyrektor... dyrektorka też: Ale o co ci chodzi? (mama 7-letniej dziewczynki).

\section{(Nie)równe traktowanie ze strony nauczycieli}

Wyniki badania potwierdzają, że nierówne traktowanie dzieci powracających pojawia się również ze strony nauczycieli. Przeprowadzone wywiady pokazują, że duża część nauczycieli wspiera dzieci w procesie adaptacji, ale zdarzają się również przypadki, w których nauczyciele przejawiają zachowania dyskryminacyjne zarówno w stosunku do dzieci, jak i rodziców (opisywane rzecz jasna przez rodziców i uczniów, nie przez samych nauczycieli). Jednym z obszarów, w których widoczna jest dyskryminacja ze strony nauczycieli, jest system oceniania. Na ogół dzieci powracające ze względu na trudności językowe i często różnice programowe muszą włożyć więcej pracy w to, aby wykonać zadania szkolne (por. Grzymała-Moszczyńska i in., 2015). Mimo to badane przez nas dzieci niejednokrotnie otrzymywały już na początku nauki w polskiej szkole 
negatywne oceny, ponieważ nauczyciele nie uwzględniali ich potrzeby zaadaptowania się do nowego systemu i nadrobienia zaległości, co powodowało, że dzieci czuły się gorsze, mniej wartościowe, traciły motywację do nauki.

I ja pierwszy raz w życiu pisałam dyktando i dostałam jedynke, bo miałam 16 błędów. I... A np. ci co maja dysleksję w ogóle nie dostali oceny, bo maja dysleksję i maja na to papiery. Trochę się tak dziwnie poczułam $z$ tym. Bo oni mają dysleksję $i$ nie dostanq oceny, bo maja powód na to, żeby źle pisać. A ja nie mam powodu, żeby źle pisać. Nie wiem, powinnam moim zdaniem dostawać ocenę za to, co umiem już i za to, co się nauczytam, a nie za to, co wszyscy inni mieli (dziewczynka, 16 lat).

Co najmniej dwóch rodziców w przebadanej próbie doświadczyło wyższościowego traktowania ze strony nauczycieli, którzy oczekiwali od rodziców postaw asymilacyjnych, a więc dostosowania się przez dzieci i rodziców do zasad panujących w polskiej szkole.

Bardzo się różniliśmy pogladami i... ta szkoła wtedy była stosunkowo młoda, to byt jej trzeci rok działania i pani dyrektor miała córkę z Maćkiem w klasie $i$ myślę, że ona też tak trochę jeszcze „na macanego" się poruszała. I jak starałam się na przykład... mówiłam różne rzeczy, które mi się nie podobaja, co można by zmienić i styszatam na przyktad na to stawne zdanie, które teraz powtarzamy wtaśnie i się śmiejemy z niego w domu: „bo tu jest Polska!” (mama 10-letniego dziecka).

B: Tak jest po prostu tutaj. 10 lat siedziałaś za granica ... Może tobie za dobrze tam byto. Może tam powinnaś wracać? Ja takie styszę tu caty czas. Tak otwarcie ludzie do mnie mówiq. A: Rozumiem, że te że po prostu dla... B: Jestem nieprzystosowana $i$ moje dzieci sq nieprzystosowane do kraju... Aha, i że Polska jest brutalnym krajem... Chcesz tu mieszkać, to się przyzwyczaj. No nie wiem... Nie muszę tu mieszkać, żeby się przyzwyczajać... A: No jasne. O poza tym też no jakby nie (mama 7-letniej dziewczynki).

\section{(Nie)uwzględnianie specjalnych potrzeb edukacyjnych dzieci powracających}

Fakt, iż nie wszyscy nauczyciele okazują dziecku powracającemu potrzebnego wsparcia, może wynikać z wielu czynników, które szerzej omawiamy w części dotyczącej dyskusji wyników. Poniżej przytaczamy najbardziej wyra- 
ziste fragmenty wypowiedzi osób badanych, ilustrujące poczucie braku zrozumienia i nie uwzględniania specjalnych potrzeb edukacyjnych w procesie nauczania.

Ona po trzech miesiacach dopiero... Ja jej powiedziałam osobiście, że dziecko jest po trzech latach nauki za granica. A ona nie zorientowata się w ogóle. A: Wogóle się nie zorientowała... B: Dyrektorka nie powiedziała no to już jest wina dyrektorki. Bo uzgadniatyśmy, że ona ja o tym poinformuje $i$ że ona poprosi ja, żeby jakoś inaczej spojrzała na dziecko. A nie... A tu nagle widze, ze to dziecko pisze te linijki, rany boskie, no to poszłam, o co jej chodzi, Jezu. Po co ona ma to pisać. A ona zdziwiona... No to ja do dyrektorki. Przecież jej mówiłam... No i nie wiem, kto teraz... (dziewczynka, 7 lat).

Nie dostat żadnego wsparcia, mimo że miat bardzo fajnq wychowawczynie, pani od angielskiego, pierwsze oceny miat trzy trójki, pani w ogóle nie umie angielskiego, przepraszam, że tak powiem. Tam mu coś próbowała udowodnić, ale mówię „nie dyskutuj”, nie zgłosiła go do konkursu, a napisat najlepiej $z$ całej szkoty, w dzień konkursu przyleciata i mówi, żeby pisat angielski. Pani uznała, ze on jest staby, nie? Staby (mama czwórki dzieci, mówi o sytuacji 15-letniego syna).

B: A powiedz czy masz takie poczucie, że jest taka chociaż jedna osoba w szkole, czy wychowawca, czy jakiś nauczyciel, czy ktoś inny, jak coś się dzieje, jak masz jakiś ktopot, do którego możesz iść? Czy jest taka osoba dla ciebie? R2: Nie (dziewczynka, 9 lat).

B: Czyli jak coś się dzieje, to właściwie nie masz do kogo się zwrócić tak? RR2: Pani B: To tak pani porozmawiataby z toba? Pomogtaby ci jakoś? R2: Ona na to nie zwraca uwagi. Mówi: „oj tam, zaraz będzie dobrze” i tak zawsze robi. B: A tutaj jest inaczej ze względu na te inne dzieci, bo maja takie nastawienie? A próbowataś do nich wychodzić z inicjatywą, zaprzyjaźnić się? R2: Tak i oni mnie.. ignorowali mnie. B: Myślisz, że to jest przez to, że przyjechałaś z innego kraju? R2: Mhm (dziewczynka, 9 lat).

Odwołując się do zebranych przez nas materiałów, można stwierdzić, że nauczyciele często nie czują się kompetentni w pracy z uczniami wielokulturowymi, wielojęzycznymi, mającymi doświadczenie migracyjne - jakimi z pewnością są dzieci z rodzin powracających. 
B: A czy w trakcie kiedy pan przygotowywat się do zawodu nauczyciela, czy pan miat jakieś zajęcia, nie wiem, z psychologii międzykulturowej, albo z pedagogiki międzykulturowej, nic?? R: W ogóle, w ogóle, w ogóle nie było nawet takiego aspektu wśród rozmaitych zagadnień dydaktycznych. To w ogóle w panoramie naszej świadomości to w ogóle nie występowało. B: Czyli kwestia, kiedy zostat pan skonfrontowany właśnie $z$ takimi dziećmi powracajacymi to polegała na własnym dośw... intuicji. R: Intuicji (nauczyciel 14-letniego chłopca).

Jedna z rozmówczyń, mama dziesięciolatka, zasygnalizowała, że nauczyciel obrażał dziecko ze względu na jego trudności edukacyjne związane z zaległościami.

Ja dam pani taki przykład. Za granica nie przyszłoby do głowy nauczycielowi, $\dot{z}$ eby powiedzieć, że jest bachorem, że jest gamoniem, że jest kim tam kolwiek innym. Syn ma orzeczona dysfunkcje, syn jest dyslektykiem i dysortografem $i$, szczerze?, nauczyciele niewiele sobie z tego robia (mama 10-letniego chłopca).

Kolejna osoba badana relacjonowała również trudności z integracją z grupą rówieśniczą, co mogło mieć związek z trudnym momentem rozwojowym, w którym zmieniła miejsce zamieszkania - z okresem dojrzewania, który jest też czasem kształtowania się tożsamości (Oleszkowicz, Senejko, 2013). Nastolatek migrant potrzebuje wsparcia ze strony nauczyciela, wychowawcy w celu zintegrowania się z rówieśnikami. Jest to utrudnione ze względu na fakt, że na tym etapie młodzież funkcjonuje już w formie ukształtowanych grup.

B: Ale mi one ogólnie zaczęty dokuczać. Bo ja jestem za dosyć niska w porównaniu do innych. I one mnie buty tak wysoko zawiesity i nie mogtam ich ściagnać $i$ ktoś mi to musiat pomagać ściagnać $i$ od tej pory ja się do nich nie odzywałam. I później zaczętam kolegować się z taka inna dziewczyną, a ona też nie jest $w$ takim moim charakterze, więc wszyscy po prostu zakodowali, że a dobra, zostawimy ich w spokoju, ona ma już koleżanki. (...) A reszta klasy? B: Znaczy nie wiem, czy oni to widzieli. Bo wszyscy sq tak sobq zajęci, wszyscy sq tak jakby w moim wieku, wszyscy sq tak dziwnie w grupy po... poustawiani. A ja tak jakby rzadko pasuje do jakiejkolwiek grupy. Z tych wszystkich grup (Weronika, 16 lat). 


\section{Wsparcie ze strony nauczycieli}

Z drugiej strony, z naszych badań wynika, że niektórzy nauczyciele potrafią stworzyć dziecku bezpieczną atmosferę i pomóc w integracji z rówieśnikami.

R: I on, też tak jakoś, ta jego to jego postawa i jego zachowanie też tak jakoś bardziej mnie zachęcito do tej klasy.

B: Mhm, co masz na myśli: przez jego postawę i zachowanie? R: Znaczy, bo on jest takim bardzo bardzo cieptym i przyjaznym człowiekiem więc, yyy... nie czułam się jakoś, jakoś, jakoś tak, jak ta nowa osoba i szybko się naprawdę zaaklimatyzowałam i już tak czułam, że to jest moja klasa nie czułam tej różnicy wieku, no bo jakby nie patrzeć, bytam rok starsza od tych osób ale nikt nie patrzyt na mnie jako na ta starsza osobe tylko, no, jak na normalna koleżankę z klasy (dziewczyna, 20 lat).

Bo, bo przecież raz, raz nawet właśnie mówiono mi w szkole, że przyjechała dziewczynka, która w ogóle nawet nie umiała powiedzieć „dzień dobry” w języku polskim. Więc bez sensu też ja zostawiać w tej samej klasie. No i wtedy właśnie pani od języka polskiego mówi tak, że widać, że ona bardzo dużo pracuje. Po prostu widać $i$ ona tutaj... nic, nie ma żadnych zastrzeżeń $i$ jest wszystko w porzadku (dziewczynka, 10 lat).

Niektórzy nauczyciele, wspierając i próbując zbudować pozycję dziecka w grupie rówieśniczej, zachęcali dzieci do podzielenia się doświadczeniami dziecka z czasu pobytu za granicą. Mimo że niektórym dzieciom sprawiało to niewielką trudność, takie działania pozwalały na łatwiejszą integrację z klasą, pomagały w procesie oswajania nowego środowiska szkolnego. Inną strategią nauczycieli było zachęcanie do indywidualnego kontaktu w trakcie przerwy.

B: yhmyhm, a czy na przyktad Michat byt poproszony, żeby opowiedziat, jak byto w tamtej szkole? R: NIE. Nie sadze. B: Bo to bytoby ciekawie ustyszeć. Od dziecka. R: No...może i tak, nie wiem... (śmiech) B: Yhmyhm R: Z drugiej strony ktoś mógtby powiedzieć, że przychodzi i sie przechwala, że byt za granica. B: yhm R: No. B: yhm R: No takie to jest. Na dwoje babka wróżyta (mama10-letniego dziecka). 
B: A powiedz mi, a opowiadateś... opowiadasz czasami kolegom swoim, jak było w Anglii? Czy w szkole opowiadateś kiedyś coś o tym? R: Yhym. Tak. B: Tak? I powiedz, czy oni sa ciekawi tego, jak tam byto, czy nie? R: Tak, sa ciekawi. Nawet pani jest ciekawa. B: Tak? Dopytuje cię? R: Jak było w Anglii? B: Yhym. R: Na poczatku mnie pytała, jak przyszłem. B: A Ty lubisz opowiadać o tym? R: Troszkę. B: Troszkę? Co to znaczy to "troszkę? R: (zastanawia się) Tak, lubię opowiadać, ale też potem nie lubię, bo... na przykład... (zastanawia sie) to też jeszcze trudno opowiedzieć, bo nie bardzo, wszystkiego tego nie pamiętam (chłopiec, 10 lat).

Tak, on opowiada tam, wie pani, o pobycie, opowiada, jak wyglada edukacja, dzieli się swoimi spostrzeżeniami i to jest dziecko bardzo otwarte i lubiane w klasie, więc... Zwiedzit, prosze pania, my byśmy to musieli (śmieje się) powiedzmy, $\dot{z}$ e, że byliśmy $i, i, i$ nie mogliśmy zobaczyć, no i być może, że, że część nie pojedzie nigdy do Anglii. A on zwiedzit. I takie sq korzyści z tego. No z chłopcem mówię, że nie ma problemu, a zwłaszcza pani z jezyka angielskiego jest $z$ niego bardzo zadowolona, prawda? (śmieje się) (nauczycielka 10-letniego chłopca).

Y, albo ona mnie pyta, albo na poczatku byto, że ona mnie caty czas pytata y, czy dzieci mi nie przeszkadzaja, czy mnie nie wyzywaja, ale teraz to jak ja mam problem, to zawsze idę do pani i jak pani coś tam coś widzi, że coś tam dzieci mi przeszkadzaja, to zawsze pyta, czy dzieci mi nie przeszkadzaja czy coś takiego (dziewczynka, 11 lat).

Dobrze jest poznać nauczycieli, naprawdę nauczyciele sa bardzo chętni, bardzo skorzy do pomocy, tylko sq na poczatku przerażeni i trzeba poczekać, aż wyjda spoza tych swoich waskich ramek, ale potem bardzo dużo pomagaja. Wymagać też tej pomocy, bo okazuje się, że jest mnóstwo takich programów pomocowych, chociażby lekcje języka polskiego, o czym ja nie wiedziałam, bo nie wiedziatam po prostu (mama trójki dzieci w wieku 5,5; 7 oraz 8 lat).

Dwie badane wskazały na konkretne metody wsparcia, które nauczyciele mogliby zastosować w celu udzielenia wsparcia uczniom i uczennicom z rodzin powracających.

B: Nie wiem, mogliby może jak ktoś tam np. jak pani mówi jak robimy zadania, to mogłaby np. podejść i zobaczyć, czy tam czy jak nie idzie zadanie, czy to rozumiem (dziewczyna, 16 lat). 
B: A czego byś oczekiwała od nauczycieli? - teraz, po tym jak wróciłaś? R: No jakiejś większej wyrozumiałości trochę. Tak żeby byli jacyś tacy chociaż troche milsi, tak wyrozumiali. Czasami o, tego się nie nauczyłam, bo też mi jest ciężko. Że: „A, nie nauczytaś się nic, tam ci dam z polskiego plus dwa $z$ odpowiedzi". No to też jest mi ciężko, bo mam i to, i to, $i$ to, a nauczyciele tak sobie myśla: a, że co ja. No nie da się tak tė̇ poświęcić jednemu przedmiotowi. Wiem, ze maja gorzej, bo chodza do szkoty i maja tego więcej, ale no ale ja wróciłam i to jest dla mnie taki szok. Bo w podstawówce było inaczej, naprawdę $i$ to jest różnica (dziewczynka, 14 lat).

\section{(Nie)równe traktowanie ze strony systemu edukacji}

Problem dyskryminacji pojawia się nie tylko na indywidualnym poziomie, w wymiarze interakcji między konkretnymi osobami. Cały system edukacji od strony formalnej, prawnej, niedostatecznie dba o równe traktowanie dzieci powracających.

Pierwszym problematycznym obszarem był i jest obowiązek udziału w egzaminach zewnętrznych. Aktualnie na podstawie pozytywnej opinii rady pedagogicznej uczeń lub uczennica objęci pomocą psychologiczno-pedagogiczną w związku z trudnościami adaptacyjnymi związanymi z wcześniejszym kształceniem za granicą mogą otrzymać zgodę na dostosowanie warunków przeprowadzania sprawdzianu i egzaminu gimnazjalnego ${ }^{7}$ do swoich możliwości. Dostosowanie to może polegać m.in. na wykorzystaniu odpowiedniego sprzętu specjalistycznego i środków dydaktycznych; odpowiednim przedłużeniu czasu przewidzianego na przeprowadzenie sprawdzianu i egzaminu gimnazjalnego; ustaleniu zasad oceniania rozwiązań zadań wykorzystywanych do przeprowadzania sprawdzianu i egzaminu gimnazjalnego uwzględniających potrzeby edukacyjne oraz możliwości psychofizyczne ucznia, oraz zapewnieniu obecności i pomocy w czasie sprawdzianu i egzaminu gimnazjalnego nauczyciela/nauczycielki wspomagającego ucznia w czytaniu lub pisaniu. Nie ma jednak możliwości dostosowania formy egzaminu, a więc np. skorzystania z arkusza tłumaczonego na język będący dla

7 W związku z reformą edukacji wchodzącą w życie w roku szkolnym 2017/2018, zakładającą likwidację gimnazjów na rzecz 8-klasowej szkoły podstawowej, uczniowie i uczennice będą podchodzić po szkole podstawowej do testu sprawdzającego wiedzę z: języka polskiego, obcego nowożytnego, matematyki oraz z jednego wybranego przez ucznia przedmiotu spośród: biologii, chemii, fizyki, geografii i historii (Wittenberg i Radwan, 2016). 
dziecka pierwszym językiem w zakresie edukacji szkolnej (Grzymała-Moszczyńska i in., 2015).

R: Ten chtopak, chodzqc już ten ostatni rok [do] gimnazjum, musiat pisać egzaminy gimnazjalne. I później jest problem. Wiadomo, że on nie napisze na tyle punktów, na ile napisze Polak cały czas mieszkajacy w Polsce. No i bała się, co będzie z rekrutacja. Czy on się dostanie po prostu do szkoty. Na szczęście tak, akurat tak napisat, że ten minimalny próg przekroczyt, więc mogliśmy go przyjać, ale to nie jest powiedziane, że akurat tak się każdemu uda. A więc praktycznie na starcie jest na gorszej pozycji (matka 16-letniej dziewczyny).

Konsekwencją zdawania egzaminu w suboptymalnych warunkach są trudności na etapie rekrutacji do szkół średnich i wyższych. Można sobie łatwo wyobrazić, że dziecko, które przyjeżdża do Polski i zostaje zakwalifikowane do trzeciej klasy gimnazjum, będzie miało dużo większe trudności z nadrobieniem materiału oraz osiągnięciem wysokich wyników w egzaminie, co może zadecydować o dalszej przyszłości edukacyjnej.

Kolejnym problemem jest trudność z kwalifikacją dzieci do konkretnej klasy. W innych systemach edukacji, np. angielskim, dzieci zaczynają szkołę podstawową w wieku 5 lat. Problem pojawia się, kiedy dziecko przyjeżdża do Polski w wieku 7 lat. Adekwatnie do polskiego systemu edukacji dziecko powinno trafić do pierwszej klasy, w systemie angielskim dziecko kontynuowałoby edukację w klasie trzeciej. Szkoły arbitralnie ustalają, do której klasy dziecko powinno uczęszczać, kierując się przesłankami takimi jak: znajomość języka polskiego, wyniki przygotowanego przez nauczyciela/ nauczycielkę testu kwalifikacyjnego czy preferencja samego dziecka lub rodziców. Kwestia ta bezpośrednio związana jest z brakiem standaryzowanych narzędzi do diagnozy pedagogicznej oraz diagnozy funkcjonowania językowego, które można byłoby wykorzystać w tej specyficznej sytuacji. Według zebranych danych nauczycielki i nauczyciele często działają zgodnie ze swoją intuicją, przy czym w kontekście braku odpowiedniej edukacji w zakresie pracy z dziećmi migrantami ich działania nie zawsze są dla dzieci korzystne (Grzymała-Moszczyńska i in. 2015).

Wiedza, że ma troszkę tyty, więc też powinni troszke przynajmniej przez te pierwsze pót roku, bo teraz to już wiadomo, im dtużej to troszkę spauzować. Chociaż no, powiem, że byt zagrożony z fizyki i chemii, bo przedmioty ścisłe to dla niego jest, gdzie to sq proste rzeczy, bo oni więcej się skupiaja na zawodo- 
wych przedmiotach, tak no, ale ciężko. No i ja tam mam swoja wychowawczynię, więc próbowałam rozmawiać. Więc ona mi powiedziała, żeby go wystać na korepetycje (matka 18-letniego chłopca).

Ostatnim dylematem związanym z nierównym traktowaniem dzieci powracających w systemie edukacji jest wsparcie przysługujące dzieciom. Akty prawne i rozporządzenia odnoszące się do praw dzieci z doświadczeniem migracyjnym w polskiej szkole regulują liczbę przysługujących dziecku dodatkowych godzin z języka polskiego i godzin wyrównawczych, możliwość zatrudnienia nauczyciela wspomagającego, asystenta kulturowego czy możliwość tworzenia oddziałów przygotowawczych ${ }^{8}$. Czasami rodzice nie byli informowani przez szkołę, że dziecko ma prawo do takiego wsparcia. W niektórych przypadkach rodzice zwracali się do szkoły z prośbą o zapewnienie dziecku dodatkowych zajęć, zdarzało się jednak, iż dostępne wsparcie nie było wystarczające. Zarówno rodzice, jak i nauczyciele podkreślali, że dwie dodatkowe godziny tygodniowo przysługujące przez rok dzieciom z doświadczeniem migracyjnym mogą być niewystarczające. Niektórzy rodzice w związku z tym decydowali się na zapewnienie dzieciom korepetycji, niekiedy matki rezygnowały na jakiś czas z pracy zawodowej po to, by pomagać dziecku na bieżąco nadrabiać zaległości szkolne. Jak łatwo się domyślić - nie wszystkie rodziny mogą sobie pozwolić na takie decyzje, gdyż wiąże się to z dużym nakładem finansowym. Niedostateczna oferta wsparcia ze strony systemu edukacyjnego przyczynia się zatem pośrednio do dyskryminowania tych rodzin powracających z migracji, które mają niższy status społeczno-ekonomiczny, powiększając tym samym już istniejące różnice pomiędzy dziećmi pochodzącymi z rodzin o różnym statusie.

\section{Wnioski i dyskusja wyników}

Wyniki badań jednoznacznie wskazują, że w narracjach badanych pojawiły się wątki związane z dyskryminacją w szkole. Dzieci powracające są narażone na zachowania dyskryminacyjne ze względu na doświadczenie migracji ze strony rówieśników oraz nauczycieli. Zjawisko to dotyczyło około 30\% próby naszych badanych, czyli 10 osób. Liczba ta może się wydawać niewielka,

8 Rozporządzenie Ministra Edukacji Narodowej z dnia 9 września 2016 roku w sprawie kształcenia osób niebędących obywatelami polskimi oraz osób będących obywatelami polskimi, które pobierały naukę w szkołach funkcjonujących w systemach oświaty innych państw (Dz.U. z 2016 r., poz. 1453) oraz Ustawa z dnia 7 września 1991 roku o systemie oświaty (Dz.U. Nr 95, poz. 425 z późn. zm.). 
warto jednak zwrócić uwagę na sposób rekrutacji osób badanych do projektu. Badani zgłaszali się dobrowolnie, co nieodmiennie prowadzić musi do niepełnej reprezentatywności próby. Opierając się na informacjach uzyskanych w szkołach i poradniach psychologiczno-pedagogicznych, mamy przekonanie, że niestety nie udało nam się dotrzeć do najbardziej trudnych i problematycznych historii rodzin, ponieważ uczniowie i rodzice z tych rodzin nie zgłaszali się do udziału w projekcie. Zatem opisane przez nas przypadki prawdopodobnie nie ilustrują najbardziej drastycznych przykładów dyskryminacji, której mogą doświadczać dzieci powracające.

Jak zostało opisane w części dotyczącej wyników dzieci z rodzin powracających doświadczały zarówno przemocy fizycznej (kopanie) jak i werbalnej (etykietowanie, przezywanie) ze strony rówieśników. Ponadto niektórzy nauczyciele przejawiali postawy dyskryminujące, nie uwzględniając specjalnych potrzeb edukacyjnych dzieci z rodzin powracających (np. ocenianie, nieuwzględnianie różnic kulturowych). Zaobserwowano także zjawisko nierównego traktowania ze strony systemu edukacji (dostosowanie wymagań podczas egzaminów czy arbitralna kwalifikacja do klasy).

Zjawisko to może wiązać się z opisaną wcześniej relacją władzy i dyskryminacji. Dzieci z rodzin powracających znajdują się z góry na mniej uprzywilejowanej pozycji - nie znają zasad panujących w szkole, mają językowe trudności, zaległości. Rówieśnicy traktują ich więc gorzej, stosując zarówno przemoc słowną, jak i fizyczną.

Rozpatrując sytuację dzieci z rodzin powracających w kontekście teorii lęku międzygrupowego, można stwierdzić, że dzieci w polskich szkołach postrzegają przybywających jako członków/członkinie grup zewnętrznych, co przejawia się poprzez wyzwiska wykorzystujące elementy związane z krajem, z którego przyjechały „nowe” dzieci. Osoby w związku z lękiem międzygrupowym mogą przejawiać strach w kontakcie z tymi osobami oraz przypisywać im wrogie intencje.

Taki lęk niwelować można poprzez kontakt z osobami z grupy „obcej” (Wojciszke, 2013). Gordon Allport zaproponował teorię redukcji uprzedzeń, którą nazwał „hipotezą kontaktu”, zakładającą, że najlepszym sposobem redukowania uprzedzeń jest bezpośredni, osobisty kontakt z członkami stereotypizowanych grup, szczególnie kiedy spełnia on cztery dodatkowe warunki: członkowie obu grup mają podobny status i wspólne cele, wzajemnie współpracują, a kontakty te są wspierane przez władze, prawo lub obyczaj (Allport, 1954, za: Wojciszke, 2013). Niestety trudno stworzyć sytuację, kiedy dzieci z grupy nieuprzywilejowanej mają równy status z grupą dyskryminu- 
jącą (Grzymała-Moszczyńska, 2013). Stosowanie więc tej teorii w sytuacji przeciwdziałania zachowaniom dyskryminacyjnym nie zawsze może spełnić swoją funkcję. Mimo to Bilewicz (2006, za: Wojciszke, 2013) na podstawie metaanalizy z udziałem ćwierć miliona badanych stwierdził, że każdy rodzaj kontaktu może być podstawą do redukcji uprzedzeń, ponieważ kontakt działa podobnie w każdym wieku i na każdym kontynencie.

Powołując się na teorię rozwoju uprzedzeń skonstruowaną przez Frances Aboud (2005), dzieci przechodzą przez różne poznawcze stadia rozwoju uprzedzeń, ale dopiero moment, w którym dzieci są w stanie myśleć abstrakcyjnie, a kategoryzacja nie jest głównym mechanizmem leżącym u podstaw dokonywanych ocen, antydyskryminacyjne interwencje są najbardziej skuteczne. Dziecko wtedy może kontrolować wiedzę na temat nabytych kategorii, oceniać jednostki pod kątem ich wewnętrznych cech. Nesdale natomiast w swojej teorii rozwoju tożsamości społecznej (2007, za: Nesdale, 2013) podkreśla, że rozwój uprzedzenia zależy od tego, jak bardzo dzieci identyfikują się z własną grupą i grupą zewnętrzną oraz na ile ta identyfikacja jest normą podzielaną przez członków grupy własnej. W obliczu tego argumentu jeszcze wyraźniej widoczne jest, iż postawy dzieci zależą zarówno od postaw rówieśników, ale też rodziców i nauczycieli.

Nauczyciele relacjonowali subiektywny brak poczucia kompetencji do pracy z dzieckiem z doświadczeniem migracyjnym, co wynika z nieporuszania takich treści podczas toku studiów. Nauczycielom brakuje wiedzy na temat wspierania uczniów i uczennic w takiej sytuacji, nie znają również sposobów reagowania na występującą w szkole przemoc. Powodem, dla którego nauczyciele nie są zdolni do zapewnienia wsparcia dzieciom z rodzin powracających, może być niewielki dostęp do kursów i szkoleń dotyczących pracy pedagogicznej z dzieckiem z doświadczeniem migracyjnym, ale również brak czasu, nacisk na realizację podstawy programowej i nadmiar obowiązków. Często zdarza się również, że nauczyciele dowiadują się, że danego dnia w ich klasie pojawi się nowe dziecko dosłownie w ostatniej chwili, tuż przed wejściem do klasy. Nie mają wówczas czasu na przygotowanie zarówno siebie, jak i klasy na przyjęcie nowego ucznia. Sytuacja jest o wiele korzystniejsza, gdy informacja taka dociera do nauczyciela z wyprzedzeniem. Może wówczas przygotować klasę na przyjęcie nowego ucznia. Ważne, aby takie zajęcia przygotować w ciekawej formie - zarówno porozmawiać, jak i przedstawić materiały wizualne, omówić kontekst kulturowy i różnice w systemach edukacji, z którego przyjedzie nowy członek klasy. Gdy uczeń się pojawi, warto poświęcić trochę czasu na zapoznanie dziecka z zasadami panujący- 
mi w szkole, poznanie przestrzeni szkolnej, poznanie rówieśników. Konkretne metody integracyjne, jak i pomocne w przygotowaniu klasy na przyjęcie ucznia z innego kontekstu kulturowego, można znaleźć w raporcie (Nie)tatwe powroty do domu. Badanie funkcjonowania dzieci powracajacych z emigracji (Grzymała-Moszczyńska i in., 2015). Kolejnym sposobem wspierania dziecka, budowania z nim relacji, a tym samym poczucia bezpieczeństwa jest zindywidualizowanie oceniania i pracy z dzieckiem $\mathrm{z}$ rodzin powracających, uwzględniając doświadczane przez to dziecko trudności.

W związku z powyższymi obserwacjami niezbędne wydaje się zmodyfikowanie lub rozszerzenie prowadzonej edukacji antydyskryminacyjnej w szkołach. Powszechna interpretacja wymogu „realizacji działań antydyskryminacyjnych obejmujących całą społeczność szkoły" poprzez wyłączne odniesienie działań do dzieci i młodzieży jest zdecydowanie zbyt wąska. Należy zwrócić również uwagę, iż brak inicjatyw wzmacniających antydyskryminacyjne kompetencje nauczycieli, nauczycielek, dyrektorów i dyrektorek, może zwrotnie obniżać jakość nauczania (Gawlicz, Rudnicki i Starnawski, 2015). Ważne byłoby umożliwienie udziału w szkoleniach antydyskryminacyjnych zarówno kadrze pedagogicznej, jak i rodzicom. Powinni oni być wyposażani w wiedzę dotyczącą specyfiki pracy z dzieckiem z doświadczeniem migracyjnym, procesów związanych z rozwojem uprzedzeń, a także sposobów przeciwdziałania dyskryminacji. Kształcenie nauczycieli wydaje nam się zadaniem szczególnie ważnym i pilnym, ponieważ to od ich i postaw, gotowości do reagowania na zachowania dyskryminacyjne oraz wyrozumiałości i wrażliwości zależy sukces adaptacyjny dzieci powracających, wielojęzycznych i wielokulturowych, których liczba będzie zapewne w najbliższym czasie gwałtownie rosnąć.

\section{Bibliografia}

Aboud, F. 2005. The Development of Prejudice in Childhood and Adolescence. In: Dovidio, J. F., Glick, L. A. and Rudman, P. eds. On the Nature of Prejudice. Fifty years after Allport. Malden: Blacwell Publishing, pp. 310-327. Allport, G. 1954. The Nature of Prejudice. Cambridge: Addison-Wesley Publishing Company.

Bilewicz, M. 2006. Kiedy kontakt osłabia uprzedzenia? Kategoryzacje społeczne i temporalne jako warunki skuteczności kontaktu międzygrupowego. Psychologia Społeczna. 1, ss. 63-74. 
Chustecka, M., Dymowska, M. i Stoecker, E. 2015. Dyskryminacja w szkole oczami młodzieży - na podstawie wywiadów grupowych z uczennicami i uczniami gimnazjów oraz szkół ponadgimnazjalnych. W: Gawlicz, K., Rudnicki, P. i Starnawski, M. red. Dyskryminacja w szkole - obecność nieusprawiedliwiona. O budowaniu edukacji antydyskryminacyjnej w systemie edukacji formalnej w Polsce. Warszawa: Towarzystwo Edukacji Antydyskryminacyjnej, ss. 79-130.

Cieślikowska, D. 2010. Dyskryminacja. W: Branka, M. i Cieślikowska, D. red. Edukacja antydyskryminacyjna. Podręcznik trenerski. Kraków: Stowarzyszenie Willa Decjusza.

Czarnecka, B. 2012. W poszukiwaniu oznak szoku kulturowego - polskie imigrantki w Wielkiej Brytanii. Studia Sociologica IV. 2, ss. 119-126.

Gawlicz, K., Rudnicki, P. i Starnawski, M. 2015. Ramy metodologiczne badań w projekcie Dyskryminacja w szkole - obecność nieusprawiedliwiona. W: Gawlicz, K., Rudnicki, P. i Starnawski, M. red. Dyskryminacja w szkole obecność nieusprawiedliwiona. O budowaniu edukacji antydyskryminacyjnej w systemie edukacji formalnej $w$ Polsce. Warszawa: Towarzystwo Edukacji Antydyskryminacyjnej, ss. 59-78.

Grant, K. E., Compas, B. E., Thurm, A. E., McMahon, S. D. and Gipson, P. Y. 2004. Stressors and Child and Adolescent Psychopathology: Measurement Issues and Prospective Effects. Journal of Clinical Child and Adolescent Psychology. 33 (2), pp. 412-425.

Grzymała-Moszczyńska, H. and Trojanek, M. 2011. Image of the world and themselves built by young Chechens living in Polish refugee centres. Intercultural conflict. In: Górak-Sosnowska, K. ed. Muslims in Poland and Eastern Europe: Widening the European Discourse on Islam. Warsaw: University of Warsaw, Faculty of Oriental Studies, pp. 69-88.

Grzymała-Moszczyńska, J. 2013. Nie ma nic bardziej praktycznego niż teoria, czyli o niektórych teoriach psychologicznych stosowanych w edukacji antydyskryminacyjnej. W: Branka, M., Cieślikowska, D. i Latkowska, J. red. (Nie)warto się różnić? Dylematy $i$ wyzwania metodologiczne edukacji antydyskryminacyjnej. Warszawa: Towarzystwo Edukacji Antydyskryminacyjnej.

Grzymała-Moszczyńska, H., Grzymała-Moszczyńska, J., Durlik, J. i Szydłowska, P. 2015. (Nie)łatwe powroty do domu? Funkcjonowanie dzieci i młodzieży powracających z emigracji. Warszawa: Fundacja Centrum im. prof. Bronisława Geremka. 
Grzymała-Moszczyńska, J. i Stoecker, E. 2015. Dlaczego warto przeciwdziałać dyskryminacji w szkole? W: Jak budować dobra szkołę? Potencjat i bariery ewaluacji w oświacie. Kraków: UJ.

Hofstede, G. 1980. Culture's consequences: international differences in work-related values. Beverly Hills, CA: Sage.

Hofstede, G. 1983. Dimensions of national cultures in fifty countries and three regions. In: Deregowski, J. B., Dziurawiec, S. and Annis, R. C. eds. Expiscations in cross-cultural psychology. Amsterdam: Swets \& Zeitlinger, pp. 335-355.

Hofstede, G. i Hofstede, J. 2007. Kultury i organizacje. Warszawa: Polskie Wydawnictwo Ekonomiczne.

Jonczy-Adamska, M. 2015. Dyskryminacja i edukacja antydyskryminacyjna w społecznościach szkolnych na podstawie wywiadów indywidualnych z nauczycielkami i nauczycielami z dużych miast. W: Gawlicz, K., Rudnicki, P. i Starnawski, M. red. Dyskryminacja w szkole - obecność nieusprawiedliwiona. O budowaniu edukacji antydyskryminacyjnej w systemie edukacji formalnej w Polsce. Warszawa: Towarzystwo Edukacji Antydyskryminacyjnej, ss.195-262.

Jurek, A. 2015. Dzieci leca pierwsza klasq. Warszawa: Fundacja na rzecz Różnorodności Społecznej.

Maslow, A. H. 1948. „Higher” and „Lower” Needs. The Journal of Psychology. 25, pp. 433-436.

Matsumoto, D. i Juang, L. 2007. Psychologia międzykulturowa. Gdańsk: GWP. Nesdale, D. 2007. Children's perception of social group. In: Zebrowski, J. A. ed. New research of social perception. Hauppauge, NJ: Nova Science Publishers, pp. 89-102.

Nesdale, D. 2013. Social Acumen. Its Role in Constructing Group Identity and Attitudes, In: Banaji, M. R. and Gelman, S. A. eds. Navigating the Social World: What Infants, Children, and Other Species Can Teach Us (Social Cognition and Social Neuroscience). Nowy York: Oxford University Press, pp. 323-331.

Oberg, K. 1960. Cultural Shock: Adjustment to New Cultural Environments. Practical Anthropology. 7, pp. 177-182.

Oleszkowicz, A. i Senejko, A. 2011. Dorastanie. W: Trempała, J. red. Psychologia rozwoju człowieka. Warszawa: Wydawnictwo Naukowe PWN, Ss. 259-286.

Rubin, K. H., Bukowski, W. i Parker, J. 1998. Peer interactions, relationships, and groups. In: Eisenberg, N. ed. Handbook of Child Psychology 
(5 ${ }^{\text {th }}$ edition): Social, emotional, and personality development. New York: Wiley, pp. 619-700.

Stemplewska-Żakowicz, K. 2009. Diagnoza psychologiczna. Diagnozowanie jako kompetencja profesjonalna. Gdańsk: GWP.

Stephan, W. G. and Stephan, C. W. 2000. An integrated theory of prejudice. In: Oskamp, S. ed. Reducing prejudiceand discrimination: The Claremont symposium on applied social psychology. Mahwah, NJ: Erlbaum Inc., pp. 23-45. Wittenberg, A. i Radwan, A. 2016. Reforma edukacji: co w 2017 roku czeka uczniów, rodziców, nauczycieli. Gazeta Prawna. [online] z dnia 27.12.2016. Protokół dostępu: http://serwisy.gazetaprawna.pl/edukacja/artykuly/1005490,reforma-edukacji-co-czeka-uczniow-rodzicow-nauczycieli. html [2000, maj 15].

Wojciszke, B. 2013. Psychologia społeczna. Warszawa: Wydawnictwo Naukowe Scholar.

Zúñiga, V. i Hamann, E. T. 2015. Going to a home you have never been to: the return migration of Mexican and American-Mexican children. Children's Geographies. 6, Vol. 13, pp. 643-655. http://dx.doi.org/10.1080/1473328 5.2014 .936364$.

\section{(Un)even treatment of returning children in Polish school}

Abstract: For a couple of years there have been a new group of school children in Poland who are very likely not to be noticed by the teaching staff, since they look like any other regular member of the class. Those children - called sometimes "invisible migrants" - are children from Polish families who have returned to Poland after a period of living abroad. After their return to Poland they are obviously enrolled into Polish schools. Unfortunately, their experiences with classmates and teachers are not always positive. Their proficiency in Polish is often not sufficient, they lack some knowledge required in the school curriculum and they often have limited cultural competencies (like addressing teachers in appropriate forms or refusing to let their schoolmates cheat during exams). Consequently, they are suffering from multiple (often intersectional) discrimination from both their peers and teachers. The paper presents some excerpts from interviews with children and their parents with a detailed analysis of such experiences.

Keywords: discrimination, migration, children, school, prejudice 